\title{
Predatory publishing solicitation: a review of a single surgeon's inbox and implications for information technology resources at an organizational level
}

\author{
Madeleine McKenzie, BSc \\ Duncan Nickerson, MD \\ Chad G. Ball, MD, MSc
}

Accepted January 11, 2021

\section{Correspondence to: \\ D. Nickerson \\ Department of Surgery, \\ University of Calgary \\ 1403-29 St NW \\ Calgary AB T2N 2T9}

duncan.nickerson@albertahealthservices.ca

DOI: $10.1503 /$ cjs. 003020

\section{SUMmary}

Over a 6-month period, roughly one-third of emails received in a single surgeon's email inbox were predatory in nature (i.e., soliciting material for nonexistent journals or conferences). While existing databases (e.g., Beall's list and The CalTech Library list of questionable conferences) catalogue many fraudulent senders, the list is ever-expanding. The overall cost to health care organizations in terms of wasted bandwidth and financial diversion is extensive, as is confusion for trainees and colleagues. For the sake of fiscal responsibility and the maintenance of scholarly standards, it is incumbent upon organizational information technology departments to continually refine strategies to reduce this adverse impact.
$\mathbf{P}$ redatory publishing or "phishing" emails purport to invite scholarly activity, but in truth actually seek to collect publishing or registration fees. ${ }^{1}$ Senders from these "journals" and/or "conferences" attempt to disguise their intent and platforms. Despite claims to the contrary, predatory journals do not provide peer review or editorial services essential steps in validating research methodology and manuscript content - nor do they offer transparent policies or processes regarding fees, longterm archiving and/or the management of potential conflicts of interest. ${ }^{2}$ The challenges incumbent in the academic, peer-reviewed literature associated with predatory journals have now become so substantial that this was the lone topic at the most recent meeting of the Surgery Journal Editors Group (SJEG). ${ }^{3}$ Although the SJEG does not have any overriding policing authority, it is an engaged group of editors from the most prominent peer-reviewed surgical journals in the world, who determine and evaluate surgical publication policy and requirements. Furthermore, our surgical trainees, research assistants and nursing collaborators are also finding it increasingly difficult to navigate the extensive web of deceitful possibilities and invitations. In the event that these journals do actually publish, the lack of adequate peer review dilutes the quality of evidence within the literature. ${ }^{4}$

\section{Case study of a single surgeon's email inboX}

All emails received by an academic surgeon at his hospital-provided email account over a 6 -month period were evaluated by 2 reviewers (M.M. and D.N.). Characteristics recorded included the site of origin, presence of grammatical errors, contact information provided, relevance of the invitation to the recipient's specialty, as well as whether the sender had already been identified as fraudulent by either Beall's list of potential predatory journals and publishers (beallslist.net) or the 
CalTech Library list of questionable conferences (https://libguides.caltech.edu/c.php?g=512665\&p=3503029).

A total of 1905 emails were received within the observation period. Of these, 608 were identified as likely to be fraudulent phishing emails and were found to consist of invitations to submit a manuscript $(46.9 \%)$, present at a conference $(34.7 \%)$, attend a conference $(9.2 \%)$, join an editorial board $(4.1 \%)$, both submit a manuscript and join an editorial board $(4.1 \%)$, contribute to an eBook $(0.7 \%)$, or review a manuscript $(0.3 \%)$. Almost all of the predatory email invitations originated from either fake journals (55.1\%) or conference hosts $(43.9 \%)$.
Phishing emails seeking manuscript submissions originated from 43 different fake publishers with 146 different journal titles (Table 1) or 8 fake stand-alone journals (Table 2). The majority of fake publishers were already included on Beall's list (86.7\%). Characteristics associated with emails suspected of being predatory included the presence of obvious spelling and/or grammar errors (90.2\%), a salutation including the word "greetings" (60.4\%; e.g., "Greetings of the day," "Greetings from...," "Warm greetings..."), an offer to submit a broad range of document/article categories $53.3 \%$; e.g., including research or review articles, case reports, editorials, clinical images, letters to editors), and/ or the use of excessively flattering language (46.7\%; Table 3 ).

Table 1 (part 1 of 3). Summary of phishing emails from predatory publishers seeking manuscript submissions

\begin{tabular}{|c|c|c|c|}
\hline Publisher & $\begin{array}{l}\text { No. }(\%) \text { of emails } \\
\text { received, } n=285\end{array}$ & Present on Beall's list & Journal titles used by predatory publisher \\
\hline Open Access Text & $42(14.7)$ & Yes & $\begin{array}{ll}\text { - } & \text { Neurology and Neuroscience Reports } \\
\text { - } & \text { Journal of Case Reports in Medicine-Trends in Transplantatio } \\
\text { - } & \text { Clinical Research and Trials } \\
\text { - } & \text { Global Surgery } \\
\text { - } & \text { Rheumatology and Orthopedic Medicine } \\
\text { - } & \text { Journal of Clinical and Molecular Medicine } \\
\text { - } & \text { Surgery and Rehabilitation Journal } \\
\text { - } & \text { Clinical and Medical Pediatrics Journal } \\
\text { - } & \text { Trends in General Practice } \\
\text { - } & \text { Physical Medicine and Rehabilitation } \\
\text { - } & \text { Clinical Microbiology and Infectious Diseases } \\
\text { - } & \text { Journal of Translational Science } \\
\text { - } & \text { Biology, Engineering and Medicine Journal } \\
\text { - } & \text { Journal of Clinical Investigation and Studies } \\
\text { - } & \text { Biomedical Research and Clinical Practice } \\
\text { - } & \text { Preventice Medicine and Community Health } \\
\text { - } & \text { Trauma and Emergency Care Journal } \\
\text { - } & \text { Cardiothoracic and Vascular Sciences } \\
\text { - } & \text { Journal of Allergy and Immunology } \\
\text { - } & \text { Journal of Translational Science } \\
\text { - } & \text { Research and Review Insights }\end{array}$ \\
\hline OMICS Publishing Group & $19(6.7)$ & Yes & $\begin{array}{l}\text { - United Journal of Physical Medicine and Rehabilitation } \\
\text { - } \quad \text { Journal of Pharmaceutical Regulatory Affairs: Open Access } \\
\text { - } \quad \text { Jourdiac and Pulmonary Rehabilitation } \\
\text { - International Journal of Physical Medicine and Rehabilitation } \\
\text { - Journal of Clinical and Experimental Transplantation } \\
\text { - Journal of Clinical Microbiology and Antimicrobials } \\
\text { - Occupational Medicine and Health Affairs } \\
\text { - } \quad \text { Anthropology Journal } \\
\text { - Journal of Phylogenetics and Evolutionary Biology } \\
\text { - Journal of Neuroinfectious Diseases }\end{array}$ \\
\hline Remedy Publications & $18(6.3)$ & Yes & $\begin{array}{ll}\text { - } & \text { Annals of Medical and Medicine Research } \\
\text { - } & \text { Journal of Surgical Techniques and Procedures } \\
\text { - } & \text { Family Medicine: Clinical Investigations and Experimental Medicine } \\
\text { - } & \text { Clinical Case Reports International } \\
\text { - } & \text { Journal of Cytology and Pathology } \\
\text { - } & \text { Journal of Dermatology and Plastic Surgery } \\
\text { - } & \text { Plastic \& Reconstructive Surgery Journal }\end{array}$ \\
\hline
\end{tabular}


Table 1 (part 2 of 3). Summary of phishing emails from predatory publishers seeking manuscript submissions

\begin{tabular}{|c|c|c|c|}
\hline Publisher & $\begin{array}{l}\text { No. }(\%) \text { of emails } \\
\text { received, } n=285\end{array}$ & Present on Beall's list & Journal titles used by predatory publisher \\
\hline Austin Publishing Group & $17(6.0)$ & Yes & $\begin{array}{ll}\text { - } & \text { Annals of Surgery and Perioperative Care } \\
\text { - } & \text { Physical Medicine and Rehabilitation } \\
\text { - } & \text { Austin Journal of Clinical Trials: Open Access } \\
\text { - } & \text { Austin Hypertension } \\
\text { - } & \text { Austin Physical Medicine } \\
\text { - } & \text { Austin Journal of Women's Health } \\
\text { - } & \text { Austin Journal of Clinical Pathology } \\
\text { - } & \text { Journal of Surgery }\end{array}$ \\
\hline Gavin Publishers & $14(4.9)$ & Yes & $\begin{array}{ll}\text { - } & \text { Archives on Veterinary Science and technology } \\
\text { - } & \text { Sports Injuries \& Medicine } \\
\text { - } & \text { Archives of Surgery and Clinical Case Reports } \\
\text { - } & \text { Applied Clinical Pharmacology and Toxicology } \\
\text { - } & \text { International Journal of Critical Care and Resuscitation } \\
\text { - } & \text { Current Trends in Clinical Trials }\end{array}$ \\
\hline Peertechz & $11(3.9)$ & Yes & $\begin{array}{ll}\text { - } & \text { International Journal of Oral and Craniofacial Science } \\
\text { - } & \text { International Journal of Veterinary Science and Research } \\
\text { - } & \text { Open Journal of Trauma } \\
\text { - } & \text { Journal of Medicinal Chemistry and Research } \\
\text { - } & \text { Internation Journal of Dermatology and Clinical Research } \\
\text { - } & \text { Journal of Novel Physiotherapy and Rehabilitation } \\
\text { - } & \text { Journal of Clinical Pharmacology and Clinical Pharmacokinetics }\end{array}$ \\
\hline ClinMed International Library & $9(3.2)$ & Yes & $\begin{array}{ll}\text { - } & \text { International Journal of Pediatric Research } \\
\text { - } & \text { International Journal of Physiatry } \\
\text { - } & \text { International Archives of Substance Abuse and Rehabilitation } \\
\text { - } & \text { International Journal of Cognition and Behaviour } \\
\text { - } & \text { Anesthesiology Case Reports } \\
\text { - } & \text { International Journal of Physical Medicine and Rehabilitation }\end{array}$ \\
\hline Allied Academies & $7(2.5)$ & Yes & $\begin{array}{ll}\text { - } & \text { Case Reports in Surgery and Invasive Procedures } \\
\text { - } & \text { Timely Topics in Clinical Immunology } \\
\text { - } & \text { Journal of Veterinary Medicine } \\
\text { - } & \text { Journal of Plant Biotechnology and Microbiology } \\
\text { - } & \text { Timely Topics in Clinical and Vaccine Research } \\
\text { - } & \text { Biology and Medicine Case ReportsClinical Trials and Vaccine Research }\end{array}$ \\
\hline SCIAEON & $7(2.5)$ & Yes & $\begin{array}{ll}\text { - } & \text { Veterinary Sciences and Medicine } \\
\text { - } & \text { Journal of Pediatric Research and Child Health }\end{array}$ \\
\hline SM Online Publishers & $7(2.5)$ & Yes & $\begin{array}{l}\text { - } \quad \text { Annals of Burns and Trauma } \\
\text { - } \quad \text { Journal of Surgical Oncology and Clinical Research } \\
\text { - }\end{array}$ \\
\hline $\begin{array}{l}\text { Global Science Library } \\
\text { Publishers }\end{array}$ & $6(2.1)$ & No & $\begin{array}{ll}\text { - } & \text { Journal of Clinical Case reports and reviews } \\
\text { - } & \text { Journal of Pediatrics } \\
\text { - } & \text { GSL Journal of Pediatrics } \\
\text { - } & \text { GSL Journal of Clinical Research and Case Reports Access } \\
\text { - } & \text { GSL Journal of Clinical Case Reports and Reviews } \\
\text { - } & \text { Internation Journal of Surgery }\end{array}$ \\
\hline Insight Medical Publishing & $6(2.1)$ & Yes & $\begin{array}{ll}\text { - } & \text { Pediatric Infectious Diseases: Open Access } \\
\text { - } & \text { Journal of Neurodegenerative Diseases and Disorders } \\
\text { - } & \text { Journal of Zoonotic Diseases and Public Health } \\
\text { - } & \text { Journal of Clinical Medicine and Therapeutics } \\
& \text { Jinical and Molecular Endocrinology }\end{array}$ \\
\hline KEI Journals & $4(1.4)$ & Yes & - $\quad$ Medical Research Archives \\
\hline Pulsus Group & $4(1.4)$ & Yes & $\begin{array}{ll}\text { - } & \text { Journal of Surgery: Case Reports } \\
\text { - } & \text { Surgery: Case Report } \\
\text { - } & \text { Journal of Addiction and Clinical Research } \\
\text { - } & \text { Pulsus Journal of Surgical Research }\end{array}$ \\
\hline Science Publishing Group & $4(1.4)$ & Yes & $\begin{array}{ll}\text { - } & \text { SPG Open } \\
\text { - } & \text { SPG Biomed }\end{array}$ \\
\hline
\end{tabular}


Table 1 (part 3 of 3). Summary of phishing emails from predatory publishers seeking manuscript submissions

\begin{tabular}{|c|c|c|c|}
\hline Publisher & $\begin{array}{l}\text { No. (\%) of emails } \\
\text { received, } n=285\end{array}$ & Present on Beall's list & Journal titles used by predatory publisher \\
\hline Scientific Literature & $4(1.4)$ & Yes & $\begin{array}{ll}\text { - } & \text { Physical Medicine and Rehabilitation } \\
\text { - } & \text { Clinical Dermatology: Research and Therapy }\end{array}$ \\
\hline SciRes Literature & $4(1.4)$ & Yes & $\begin{array}{l}\text { - American Journal of Burns and Trauma } \\
\text { - } \quad \text { Open Journal of Surgery }\end{array}$ \\
\hline SciTechnol & $4(1.4)$ & Yes & $\begin{array}{ll}\text { - } & \text { Clinical Dermatology Research Journal } \\
\text { - } & \text { Archives on Clinical Pathology } \\
\text { - } & \text { Journal of Plastic Surgery and Cosmetology } \\
\text { Journal of Clinical Nutrition and Metabolism }\end{array}$ \\
\hline Somato Publications & $4(1.4)$ & No & - Journal of Dermatology and Cosmetic Surgery \\
\hline Crimson Publishers & $3(1.1)$ & Yes & $\begin{array}{ll}\text { - } & \text { Advancements in Bioequivalence \& Bioavailability } \\
\text { - } & \text { Examines in Physical Medicine \& Rehabilitation } \\
\text { - } & \text { Orthoplastic Surgery \& Orthopedic Care International Journa }\end{array}$ \\
\hline $\begin{array}{l}\text { Herald Scholarly Open } \\
\text { Access }\end{array}$ & $3(1.1)$ & Yes & $\begin{array}{ll}\text { - } & \text { Journal of Otolaryngology, Head \& Neck Surgery } \\
\text { - } & \text { Journal of Brain and Neuroscience Research } \\
\text { - } & \text { Journal of Clinical Dermatology and Therapy }\end{array}$ \\
\hline MedCrave & $3(1.1)$ & Yes & $\begin{array}{ll}\text { - } & \text { Journal of Pediatrics and Neonatal Care } \\
\text { - } & \text { Journal of Psychology \& Clinical Psychiatry } \\
\text { - } & \text { Journal of International Physical Medicine \& Rehabilitation }\end{array}$ \\
\hline Symbiosis Online Publishing & $3(1.1)$ & Yes & $\begin{array}{ll}\text { - } & \text { SOJ Surgery } \\
\text { - } & \text { international Journal of Open Access Ophthalmology } \\
\text { - } & \text { International Journal of Open Access Clinical Trials }\end{array}$ \\
\hline Bioaccent Publishing & $2(0.7)$ & Yes & - $\quad$ BAOJ Bioinformatics \\
\hline Chronicle Publishers & $2(0.7)$ & No & $\begin{array}{l}\text { - Chronicle Journal of Epidemiology and Preventive Medicine } \\
\text { - Journal of Clinical Case Reports and Reviews }\end{array}$ \\
\hline $\begin{array}{l}\text { Gratis Open Access } \\
\text { Publishing }\end{array}$ & $2(0.7)$ & Yes & - Integrative Pediatrics and Child Care \\
\hline $\begin{array}{l}\text { Heighten Science } \\
\text { Publications }\end{array}$ & $2(0.7)$ & Yes & $\begin{array}{l}\text { - Journal of Novel Physiotherapy and Rehabilitation } \\
\text { - } \quad \text { Journal of Advanced Pediatrics and Child Health }\end{array}$ \\
\hline Longdom Publishing & $2(0.7)$ & Yes & $\begin{array}{l}\text { - Journal of Reconstructive Surgery and Anaplastology } \\
\text { - Journal of Clinical and Experimental Pharmacology }\end{array}$ \\
\hline Madridge Publishers & $2(0.7)$ & Yes & Madridge Journal of Surgery \\
\hline Research Open & $2(0.7)$ & Yes & Integrative Journal of Veterinary Biosciences \\
\hline Scholarly Pages & $2(0.7)$ & Yes & $\begin{array}{l}\text { - } \quad \text { Clinical Pediatrics and Research Journal } \\
\text { - Journals of Scholarly Pages }\end{array}$ \\
\hline Science Repository & $2(0.7)$ & Yes & Surgical Case Reports \\
\hline Annex Publishers & $1(0.4)$ & Yes & - Journal of Physical Medicine and Rehabilitation Studies \\
\hline Avens Publishing Group & $1(0.4)$ & Yes & Journal of Clinical Trials and Patenting \\
\hline Bibliotics Journals & $1(0.4)$ & No & Journal of Orthopaedics Spine and Sports Medicine \\
\hline Boffin Access & $1(0.4)$ & Yes & International Journal of Veterinary and Animal Medicine \\
\hline Edorium Journals & $1(0.4)$ & No & Edorium Journals \\
\hline JSciMed Central & $1(0.4)$ & Yes & Annals of Sports Medicine and Research \\
\hline Juniper Publishers & $1(0.4)$ & Yes & Modern Applications of Bioequivalence \& Bioavailability \\
\hline Meddocs Online & $1(0.4)$ & No & Journal of Abdominal Wall Reconstruction \\
\hline Ommega Publishers & $1(0.4)$ & Yes & Journal of Pediatrics and Palliative Care \\
\hline Onjourn Publishers & $1(0.4)$ & Yes & Case Reports and Literature Review Journal \\
\hline ScholArena & $1(0.4)$ & Yes & Journal of Veterinary and Animal Reseacrh \\
\hline Scimaze Publishers & $1(0.4)$ & Yes & - $\quad$ Scimaze Pediatrics \\
\hline Scitechz & $1(0.4)$ & Yes & - $\quad$ Annals of Clinical and Medical Case Reports \\
\hline
\end{tabular}

The majority of the predatory conference invitations $(97.4 \%)$ originated from 14 unique fake hosts, of which more than half $(57.1 \%)$ were present on CalTech Library's list of questionable conferences (Table 4). In the absence of a comprehensive list of fake conference hosts to rely on, characteristics such as the presence of spelling and/or grammar errors
$(73.0 \%)$, use of the word "greetings" (41.2\%), appealing words in the conference title giving it an international appearance (74.9\%; e.g., global, world, euro), and the use of excessively flattering language (42.7\%) are often helpful (Table 5).

Nearly all publishers and stand-alone journals $(91.9 \%)$, as well as the majority of conference hosts 
Table 2. Summary of phishing emails from predatory stand-alone journals seeking manuscript submissions

\begin{tabular}{lcc} 
Jounal & No. (\%) of emails received, $n=285$ & Present on Beall's list \\
\hline Clinics in Surgery & $28(9.8)$ & Yes \\
\hline World Journal of Surgery and Surgical Research & $10(3.5)$ & No \\
\hline Accura Science & $6(2.1)$ & No \\
\hline United Journal of Physical Medicine and Rehabilitation & $3(1.1)$ & No \\
\hline Annals of Clinical Case Reports & $1(0.4)$ & Yes \\
\hline International Journal of Animal Science & $1(0.4)$ & No \\
\hline International Journal of Critical Care and Trauma & $1(0.4)$ & No \\
\hline Journal Surgery Research and Reports & $1(0.4)$ & No
\end{tabular}

Table 3. Characteristics of phishing emails seeking manuscript submissions

Characteristic

No. $(\%)$ of emails received, $n=285$

Email origin

Sent from free provider (e.g., gmail.com)

Purported country of origin

None mentioned $139(48.8)$

USA $120(42.1)$

UK $18(6.3)$

Italy $4(1.4)$

Greece $1(0.4)$

Japan $1(0.4)$

South Korea $1(0.4)$

Switzerland $1(0.4)$

Email salutation

Generic $49(17.2)$

Absent 7 (2.5)

Addressed to wrong name $3(1.1)$

"Greetings..." 172 (60.4)

Journal characteristics

Impact Factor cited 28 (9.8)

ISSN number cited 48 (16.8)

Claim to offer editorial services and/or a peer review process $108(37.9)$

Claim to be open access $78(27.4)$

Claim to offer short publication time 44 (15.4)

Broad range of documents accepted (e.g., research, review, 152 (53.3)

case report, editorial, clinical image, letter to editor)

Discounted publication fee mentioned 49 (17.2)

Publisher/standalone journal online presence

Organization has a website

$262(91.9)$

Organization is verifiable online (i.e., listed on PubMed $0(0)$

External links provided within the email 157 (55.1)

An "unsubscribe" mechanism is available $133(46.7)$

Disclaimer present at the end of the email 53 (18.6)

Email language

Presence of spelling or grammar errors $\quad 258(90.5)$

Use of flattery 133 (46.7)

Deadline to respond is given $153(53.7)$

Use of appealing words to make the journal appear international 48 (16.8)

(e.g., global, world, euro)

Email contact information

$\begin{array}{ll}\text { Phone number } & 107 \text { (37.5) }\end{array}$

Street address 109 (38.2)

Email Relevance to surgeon's discipline

Previous publications by the recipient are cited in the invitation 24 (8.4)

Invitation is related to surgeon's specialty

$84(29.5)$ 
$(71.2 \%)$ identified as potentially predatory in nature were associated with a website; therefore, online verification is not a reliable way of determining the legitimacy of a phishing email.

\section{Discussion}

Receiving an email invitation to submit a manuscript should raise a red flag, given that most legitimate journals and publishers rarely solicit manuscript submissions. Based on our review, we suggest authenticating these emails by looking for characteristics indicative of a predatory email, including spelling and grammar errors, overly formal or stilted salutations, and a broad range of welcomed submission types (original articles, review articles, case reports, editorials, clinical images, letters to editors), and by consulting Beall's list to look for the publisher or journal name.

Our institution's information technology (IT) department estimates that on a monthly basis, an average of 21 million out of 31 million emails to 120000 distinct users are blocked by firewalls (Alberta Health Services employee website, 2019 Nov. 28). Our data also suggest that of the 10 million emails that penetrate these firewalls, potentially onethird are phishing emails. This clearly highlights the need for improvement to firewall/sequestration practices. For an organization of 100000 users, earning an average of $\$ 100000$ per year, and receiving 6 spam emails a day, the cost in terms of storage, management, downtime, and lost productivity has been estimated to be greater than $\$ 16$ million per

Table 4. Sumary of predatory conference invitations sent from fake hosts

\begin{tabular}{|lcc|}
\hline Conference hosts & $\begin{array}{c}\text { No. (\%) of emails } \\
\text { received, } n=267\end{array}$ & $\begin{array}{c}\text { Present in } \\
\text { CalTech Library } \\
\text { listing }\end{array}$ \\
\hline Conference Series LLC Ltd & $128(47.9)$ & Yes \\
\hline BioEvents & $27(10.1)$ & No \\
\hline EuroSciCon & $21(7.9)$ & Yes \\
\hline PULSUS Group & $20(7.5)$ & Yes \\
\hline Allied Academies & $17(6.4)$ & Yes \\
\hline Scientific Federation & $14(5.2)$ & Yes \\
\hline WONCA & $12(4.5)$ & No \\
\hline Meetings International Pte Ltd & $6(2.2)$ & Yes \\
\hline WSP & $6(2.2)$ & Yes \\
\hline BioGenesis & $1(0.4)$ & No \\
\hline BIT Congress Inc & $1(0.4)$ & No \\
\hline OMICS International & $1(0.4)$ & N/A \\
\hline Pharma Professionals & $1(0.4)$ & $1(0.4)$ \\
\hline $\begin{array}{l}\text { Scientific Overseas Group } \\
\text { Conferences }\end{array}$ & $7(2.6)$ & \\
\hline $\begin{array}{l}\text { Unable to determine conference } \\
\text { provider }\end{array}$ & & \\
\hline
\end{tabular}

Table 5 (part 1 of 2). Characteristics of predatory conference invitations

\begin{tabular}{|c|c|}
\hline Parameters & $\begin{array}{c}\text { No. (\%) of } \\
\text { emails received, } \\
n=267\end{array}$ \\
\hline \multicolumn{2}{|l|}{ Email origin } \\
\hline Email sent from a free provider like gmail.com & $3(1.1)$ \\
\hline \multicolumn{2}{|l|}{ Purported country of origin } \\
\hline UK & $124(46.4)$ \\
\hline None mentioned & $114(42.7)$ \\
\hline India & $7(2.6)$ \\
\hline Singapore & $7(2.6)$ \\
\hline Italy & $6(2.2)$ \\
\hline USA & $6(2.2)$ \\
\hline Canada & $1(0.4)$ \\
\hline China & $1(0.4)$ \\
\hline Luxembourg & $1(0.4)$ \\
\hline \multicolumn{2}{|l|}{ Purported country of conference location } \\
\hline UK & $31(11.6)$ \\
\hline USA & $25(7.9)$ \\
\hline Spain & $21(7.9)$ \\
\hline None mentioned & $20(7.5)$ \\
\hline Japan & $20(7.5)$ \\
\hline Italy & $19(7.1)$ \\
\hline South Korea & $12(4.5)$ \\
\hline United Arab Emirates & $11(4.1)$ \\
\hline Russia & $10(3.7)$ \\
\hline Singapore & $10(3.7)$ \\
\hline Australia & $8(3.0)$ \\
\hline Austria & $8(3.0)$ \\
\hline Canada & $8(3.0)$ \\
\hline Thailand & $8(3.0)$ \\
\hline Czech Republic & $7(2.6)$ \\
\hline Germany & $6(2.2)$ \\
\hline Malaysia & $6(2.2)$ \\
\hline Scotland & $5(1.9)$ \\
\hline China & $4(1.5)$ \\
\hline Ireland & $4(1.5)$ \\
\hline Switzerland & $4(1.5)$ \\
\hline France & $3(1.1)$ \\
\hline The Netherlands & $3(1.1)$ \\
\hline Norway & $3(1.1)$ \\
\hline Hungary & $2(0.7)$ \\
\hline New Zealand & $2(0.7)$ \\
\hline Portugal & $2(0.7)$ \\
\hline Denmark & $1(0.4)$ \\
\hline Greece & $1(0.4)$ \\
\hline India & $1(0.4)$ \\
\hline Turkey & $1(0.4)$ \\
\hline Sweden & $1(0.4)$ \\
\hline \multicolumn{2}{|l|}{ Email salutation } \\
\hline Addressed by name & $74(27.7)$ \\
\hline Generic & $123(46.1)$ \\
\hline Absent & 45 (16.9) \\
\hline Addressed to wrong name & $24(9.0)$ \\
\hline "Greetings..." & $110(41.2)$ \\
\hline \multicolumn{2}{|l|}{ Conference host online presence } \\
\hline Organization has a website & $190(71.2)$ \\
\hline External links provided within the email & 256 (95.9) \\
\hline
\end{tabular}




\begin{tabular}{|c|c|}
\hline Parameters & $\begin{array}{c}\text { No. }(\%) \text { of } \\
\text { emails received, } \\
n=267\end{array}$ \\
\hline An "unsubscribe" mechanism is available & 231 (86.5) \\
\hline Disclaimer present at the end of the email & $91(34.1)$ \\
\hline \multicolumn{2}{|l|}{ Email language } \\
\hline Presence of spelling or grammar errors & $195(73.0)$ \\
\hline Use of flattery & $114(42.7)$ \\
\hline A conference date is provided & $224(84.0)$ \\
\hline $\begin{array}{l}\text { Use of appealing words to make the conference } \\
\text { appear international (e.g., global, world, euro) }\end{array}$ & $200(74.9)$ \\
\hline \multicolumn{2}{|l|}{ Email relevance to surgeon's specialty } \\
\hline $\begin{array}{l}\text { Previous publications by the recipient are cited in the } \\
\text { invitation }\end{array}$ & $3(1.1)$ \\
\hline Invitation is related to surgeon's specialty & $5(1.4)$ \\
\hline
\end{tabular}

year. ${ }^{5}$ Our study also identified the types of words firewalls could flag to block predatory emails. They included the names of journals and publishers listed on Beall's list; the names of conference hosts listed on the CalTech Library list; the names of journals, publishers and conference hosts we deemed to be predatory; the word "greetings"; and the presence of obvious spelling and/or grammar errors.

\section{Conclusion}

In our experience, unsolicited emails mostly consisted of invitations from predatory publishers with associated (or stand-alone) journals seeking manuscript submissions. Emails from predatory conference hosts inviting recipients to attend or present at a fake conference are also frequent. The costs associated with this type of spam in large organizations can be in the millions of dollars. These emails shared common characteristics which, together with PubMed's indexed list, as well as both Beall's list and the CalTech Library list, can be used by recipients to distinguish between legitimate and predatory invitations.

Affiliations: From the Department of Surgery, University of Calgary, Calgary, Alta.

Competing interests: C.G. Ball is coeditor-in-chief of C7S. He was not involved in the review or decision to accept this manuscript for publication. No other competing interests declared.

Contributors: All authors contributed substantially to the conception, writing and revision of this article and approved the final version for publication.

Content licence: This is an Open Access article distributed in accordance with the terms of the Creative Commons Attribution (CC BY-NC-ND 4.0) licence, which permits use, distribution and reproduction in any medium, provided that the original publication is properly cited, the use is noncommercial (i.e., research or educa- tional use), and no modifications or adaptations are made. See: https://creativecommons.org/licenses/by-nc-nd/4.0/

\section{References}

1. Shamseer L, Moher D, Maduekwe O et al. Potential predatory and legitimate biomedical journals: can you tell the difference? A crosssectional comparison. BMC Med 2017;15:28.

2. Sharma H, Verma S. Predatory journals: the rise of worthless biomedical science. 7 Postgrad Med 2018;64:226-31.

3. Surgery Journal Editors Group. Consensus statement on the adoption of the COPE guidelines. Am F Surg 2010;200:1-2.

4. Franco EL. The downside of the shifting paradigm of scholarly publishing in the biomedical sciences: predatory publishing. 7 Obstet Gynaecol Can 2017;39:513-5.

5. Spam cost calculator. Edmonton (Alta.): SpyderMail. Available: https://www.spydermail.com/spam-cost-calculator/ (accessed 2019 Dec. 12). 